\title{
Policy, Politics and Beer: A 30-Year Conversation with Peter deLeon
}

Hank C. Jenkins-Smith

\section{(2) OpenEdition \\ 1 Journals}

Electronic version

URL: http://journals.openedition.org/irpp/1207

DOI: 10.4000/irpp.1207

ISSN: 2706-6274

Publisher

International Public Policy Association

\section{Printed version}

Date of publication: 1 September 2020

Number of pages: 131-132

ISSN: 2679-3873

\section{Electronic reference}

Hank C. Jenkins-Smith, "Policy, Politics and Beer: A 30-Year Conversation with Peter deLeon", International Review of Public Policy [Online], 2:2 | 2020, Online since 01 September 2020, connection on 29 January 2021. URL: http://journals.openedition.org/irpp/1207 ; DOI: https://doi.org/10.4000/irpp. 1207

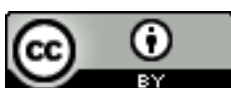

International Review of Public Policy is licensed under a Creative Commons Attribution 4.0 International. 


\section{Policy, Politics and Beer: A 30-Year Conversation with Peter deLeon}

\section{Hank C. Jenkins-Smith}

University of Oklahoma

Peter deLeon will be remembered and greatly missed for many reasons - for his accomplishments, his commitments, and the quality of his personal engagements. With Peter, it was possible to have a "conversation" that spanned decades. I had the good fortune to engage in such a conversation (and I know from colleagues that this was not an uncommon practice for Peter) that lasted for over 30 years. This conversation was at times serious but often laced with Peter's hilarious (and sharp!) wit, engaging his extraordinarily broad knowledge and deep intelligence. In our case, the conversation initially focused the role of policy analysis in democracy, and gradually broadened to consider the possibility of sustainable democratic governance. It spanned arguments over the philosophy, methodology, and practice of public policy analysis ${ }^{1}$. But the heart and soul of this decades-long conversation concerned the relationship between policy analysis and democracy.

One of Peter's most widely read works focused on the "policy sciences", expanding on Harold Laswell's agenda to bring interdisciplinary scholarship to bear on improving the human condition. Peter argued that the policy sciences were vital for democracies. For him, as for Harold Lasswell, this was an urgent task because democracy and human progress are far from inevitable. Building sustainable democratic norms requires a deep and systematic understanding of people and institutions, and translating that understanding (via policy analysis tools) to policy makers. In Advice and Consent (1989), Peter argued that the (then) increasingly prominent role of policy scientists had resulted from the advancement of systematic analytical tools (chiefly from operations research) and the growth of institutional norms among decision makers that such advice should be sought and - at least occasionally - relied upon. But it had become clear that the provision of advice based on some set of criteria for an optimal solution was not readily employed by decision-makers, and dispassionate "optimization" had failed to garner broad public support. For that reason, Peter sought to better understand and promote a form of "democratic policy analysis" that would rely heavily on processes that enable input from the affected publics (deLeon 1992, 1997). He recognized that deep public engagement could be (and in some cases should be) slow (like the cumbersome and bureaucratic Environmental Impact Assessment process in the US), but argued that judicious application of participatory forms of policy analysis could lead to a deepening and broadening of both public engagement and democratic legitimacy in policy making. In Peter's view, hope for both the legitimacy of the policy sciences and (maybe most importantly) robust and sustainable democratic governance depended on making the transition from dispassionate, top-down policy analysis to a more bottom-up, stakeholder-infused form of policy analysis.

Peter's wit was irrepressible. At one point we devised ${ }^{2}$ a game in which we took turns offering a word or phrase that the other was challenged to include in a peer-reviewed, published work

1 - We agreed (by my calculation) approximately $61.6 \%$ of the time - but that is beside the point.

2 - Or perhaps we re-invented it. Surely someone else had previously played this or a similar game, and if so I'd dearly love to hear about it. 
within the next year. The clock began ticking as soon as the word was conveyed. The game required that the use of the word make sense and fit into the context of the published work. The game lasted about 5 years, and it ended in a draw. The last challenge he gave me was to include "auto-da-fay" in a paper. I used the phrase in reference to the public defeat of an attempt to site a nuclear power plant. My last challenge to him - given his decidedly non-mechanistic way of looking at the world - was "sprocket". And I challenge the reader to find Peter's published use of that word (It exists. Let me know if you find it and we will lift a glass together in Peter's honor.). Other forays of Peter's humor, woven through decades of conversation, concerned the name of the beer I was attempting to perfect ("Skin of the Lizard" brew, circa late 1990s) and a deeply philosophical discussion and non-quantitative analysis of the names of the cows in the film "Cold Comfort Farm".

Peter's keen wit was also evident in his genial skepticism of quantification and formalism in policy analysis. I recall his delight in criticizing methods-heavy pieces as tending to "produce very little after enormous [methodological] exertion". Since my own work is (sometimes) of a quantitative nature, this involved quite a lot of friendly jousting over the years - and through it all Peter engaged with a kind of dogged joy ${ }^{3}$ and relish that made it impossible to take offense. And in his criticisms he was all too often right on the mark.

Over the last few decades, as norms for reliance on analytically sound advice (and on sciencebased decision-making more generally) among American policy makers and large segments the public have eroded, my conversation with Peter more frequently took on an ominous tone. In the near term, at least, the as yet unrealized promise of the policy sciences increasingly seemed remote. In the American political context, the looming threat of climate change and polarized partisan beliefs seemed to deeply challenge the prospects for democratic policy analysis. Yet Peter remained optimistic about the long haul, irreverent about current leaders and trends, and convinced that the democratic policy sciences would play a key role in addressing the growing challenges to the human prospect.

My 30-year conversation Peter will continue to echo in my thoughts and influence my work for as long as I am able to work. That conversation, and his friendship, are among my most valuable professional experiences. Throughout our exchanges Peter was erudite, thoughtful, humorous, careful, sharp, and courageous. He was, above all, consistently decent and kind. I will miss him.

Carlson, D., Haeder, S., Jenkins-Smith, H., Ripberger, J., Silva, C., \& Weimer, D. (2019). Monetizing Bowser: A Contingent Valuation of the Statistical Value of Dog Life. Journal of Benefit-Cost Analysis, 11(1), 131-149.

DeLeon, P. (1989). Advice and Consent: The Development of the Policy Sciences. New York, NY: Russell Sage Foundation.

DeLeon, P. (1992). The Democratization of the Policy Sciences. Public Administration Review, 52, 125-129.

DeLeon, P. (1997). Democracy and the Policy Sciences. New York, NY: SUNY Press.

3 - I cannot resist, in Peter's honor, referencing a recent paper (of which I am a co-author) that estimates the statistical value of a dog's life (Carlson et al, 2019). Really. Peter would have loved it! 